\title{
AUTONOMIC HYPERREFLEXIA DURING CYSTOSCOPY IN PATIENTS WITH HIGH SPINAL CORD INJURIES
}

\author{
By J. C. Snow, ${ }^{1}$ M.D., H. P. Sideropoulos, M.D., B. J. KRIPKe, M.D., M. M. Freed, \\ M.D., N. K. SHAH, M.D. and R. M. Schlesinger, M.D. \\ Boston University School of Medicine and University Hospital, Boston, \\ Massachusetts 02118, U.S.A.
}

Abstract. Cystoscopic procedures were performed on 102 patients with histories of traumatic spinal cord lesion; 57 patients had sensorimotor levels above $\mathrm{T}_{7}$, and the remaining 45 patients had levels below $T_{7}$. In 40 of the 57 patients (70 per cent) with levels above $\mathrm{T}_{7}$, signs and symptoms of autonomic hyperreflexia were seen during bladder distension and cystoscopy; the remaining 17 of these patients ( 30 per cent) did not have this response. No autonomic hyperreflexia was seen during cystoscopy in any of the 45 patients with sensorimotor levels below $\mathrm{T}_{7}$.

Key words: Autonomic hyperreflexia; cystoscopy.

\section{Introduction}

THE paraplegic or tetraplegic patient receives multiple insults, beginning with the initial injury to his spinal cord and progressing through many blood transfusions; plastic surgical operations for decubitus ulcers; and orthopaedic, neurologic, and numerous urologic surgical procedures for complications that develop during the period of rehabilitation (Desmond, I970).

Guttmann and Whitteridge (I947) were the first to observe that when the lesion was located below the T6, vasoconstriction of the toes was accompanied by vasodilation of the fingers and an increase in the systolic blood pressure. If the injury was situated above the $\mathrm{T}_{5}$, vasoconstriction of the toes was accompanied by vasoconstriction of the fingers and a marked rise in arterial blood pressure (70-160 torr) with a decrease in pulse rate. Bladder distension was the stimulus used for this investigation (Guttmann \& Whitteridge, I947; Guttmann, 1976).

Patients with cervical or high thoracic spinal cord injuries very often develop autonomic hyperreflexia during urologic surgical procedures, particularly during distention of the bladder with irrigating fluid and subsequent cystoscopy. Due to the exaggeration of abnormal reflexes that occur below the level of the spinal cord lesion following the excessive response to normal stimuli, the patient may develop paroxysmal hypertension, bradycardia, sweating (Head \& Riddoch, I9I 7) vasodilation above and vasoconstriction below the lesion, blurred vision, a throbbing headache, facial flushing, and pilomotor activity (Guttmann \& Whitteridge, 1947). Occasionally nasal congestion, mydriasis, and electrocardiographic changes may appear. The hypertensive response may be severe enough to precipitate fatal cerebral and subarachnoid haemorrhage (Kurnick, 1956; Bors \& Comarr, I97I).

The purpose of this communication is to report on the frequency of appearance, complications, and therapy of autonomic hyperreflexia in patients with high spinal cord injuries during urinary bladder examination, as has been observed at University Hospital in Boston during a 5-year period, and once again to bring this important condition to the anaesthesiologist's attention.

1 Boston University School of Medicine and University Hospital, 75 East Newton Street, Boston, Mass. 02 I 18 , U.S.A. 


\section{Materials and Methods}

During the 5-year period covered by this study (I July I970 through I July 1975), 364 patients with histories of spinal cord injury were admitted to the Spinal Cord Injury Center of University Hospital in Boston (63 patients were admitted more than once). These were all traumatic paraplegics and quadriplegics; patients with spinal cord dysfunction due to such conditions as syringomyelia, poliomyelitis, Guillain-Barré syndrome, Parkinson's disease, or tumours were not considered in this study.

Of these 364 patients, 174 entered the operating rooms for a variety of surgical procedures, most commonly cystoscopy, cystometrogram, transurethral removal of bladder stones, transurethral resection of the bladder neck, debridement and/or gluteal flap rotation for sacral and ischial decubitus ulcers, and inferior vena cava plication. (Many of these I 74 patients underwent more than one surgical procedure.)

Preoperatively, an anaesthesia history was obtained from each patient, and a physical examination was done. In re-admission cases, prior hospital records were studied. The sensorimotor levels were determined by careful neurologic evaluation. One hour prior to cystoscopy, a sedative drug (diazepam Io mg or pentobarbital I00 $\mathrm{mg}$ ) was administered intramuscularly.

In the operating room, prior to cystoscopy, the electrodes of the electrocardioscope, with a heart rate meter and electrocardiogram, were attached on the patient's chest, the tracing corresponding approximately to leads I and II; a blood pressure cuff was placed on the arm; and a continuous intravenous infusion through an I8-gauge plastic catheter, with $1000 \mathrm{ml}$ of Ringer's lactate in 5 per cent $\mathrm{D} / \mathrm{W}$, was started in an upper extremity. A trimethaphan (Arfonad) 0.1 per cent solution in 5 per cent $\mathrm{D} / \mathrm{W}$ was readily available for therapy in case paroxysmal hypertension developed.

A patient was considered to be exhibiting autonomic hyperreflexia if the systolic blood pressure showed an increase of more than 40 torr (as compared with the preoperative level), with a simultaneous decrease in heart rate.

\section{Results}

Of these I 74 patients with histories of traumatic spinal cord lesion who had surgery, 57 patients had sensorimotor levels above $\mathrm{T}_{7}$, and the remaining $\mathrm{I}_{7} \mathrm{~h}$ had levels below $\mathrm{T}_{7}$. Direct visual examination of the urinary tract with the cystoscope was performed with or without sedative drugs, local or general anaesthesia on I02 patients, of whom 57 had levels above $\mathrm{T}_{7}$ and 45 had levels below $\mathrm{T}_{7}$.

The age range of these 57 patients (see Table) with sensorimotor levels above $\mathrm{T}_{7}$ was $15-65 ; 54$ were male and three female. Most of the cystoscopies were carried out with mild sedation with intravenous administration of diazepam 5-10 $\mathrm{mg}$ and thiopental 25-50 mg. No local anaesthesia was necessary. However, occasionally general anaesthesia was required for endoscopic diagnosis and surgery in order to control troubling reflex contraction of the trunk and lower extremity musculature. In nine of the 57 patients with level above $\mathrm{T}_{7}$, the cystoscopies were performed under general anaesthesia (nitrous oxide, oxygen, and thiopental). Most of the cystoscopic procedures were followed by panendoscopy, cystogram, cystometrics, removal of the bladder stones or resection of the bladder neck.

Signs and symptoms of autonomic hyperreflexia were seen during bladder distension and cystoscopy in 40 (70 per cent) of the patients with sensorimotor levels above $T_{7}$, while in the remainder ( 17 patients) no signs were observed. No 
TABLE

Characteristics of 57 patients with traumatic spinal cord lesion above $\mathrm{T}_{7}$ undergoing cystoscopy

\begin{tabular}{|c|c|c|c|c|c|c|c|c|}
\hline \multirow[t]{2}{*}{ Case } & \multirow[t]{2}{*}{ Age } & \multirow[t]{2}{*}{ Sex } & \multirow{2}{*}{$\begin{array}{l}\text { Sensory } \\
\text { level }\end{array}$} & \multirow{2}{*}{$\begin{array}{l}\text { Year and cause } \\
\text { of accident }\end{array}$} & \multirow{2}{*}{$\begin{array}{l}\text { Number of } \\
\text { cystoscopies }\end{array}$} & \multicolumn{2}{|c|}{ Anaesthesia } & \multirow{2}{*}{$\begin{array}{l}\text { Increased } \\
\text { systolic BP } \\
\text { more than } \\
40 \text { torr }\end{array}$} \\
\hline & & & & & & Sedation & General & \\
\hline I & 59 & M & $\mathrm{C}_{5}$ & I970/Industrial & 3 & $\times$ & & Yes* \\
\hline 2 & 56 & M & $\mathrm{C}_{7}$ & I967/Fall & I & $\times$ & & Yes \\
\hline 3 & I 8 & M & C6 & I970/Diving & 3 & & $x$ & Yes* \\
\hline 4 & 25 & M & C6 & I970/Diving & $\mathbf{I}$ & $x$ & & No \\
\hline 5 & 19 & $M$ & C6 & I969/Automobile & 2 & $x$ & & Yes* \\
\hline 6 & $3 I$ & $M$ & $\mathrm{C}_{7}$ & I970/Diving & I & & $x$ & Yes \\
\hline 7 & 19 & M & $\mathrm{C}_{7}$ & I970/Fall & 3 & $x$ & & Yes* \\
\hline 8 & 38 & $M$ & $\mathrm{C}_{5}$ & I969/Fall & 4 & $\times$ & & Yes* \\
\hline 9 & 28 & $M$ & T6 & I969/Automobile & 3 & $x$ & & No \\
\hline IO & 44 & $M$ & $\mathrm{~T}_{4}$ & I95I/Fall & I & & $x$ & Yes \\
\hline I I & 24 & M & $\mathrm{C}_{7}$ & I97I/Automobile & I & $x$ & & Yes \\
\hline I2 & 65 & M & $\mathrm{C}_{5}$ & I962/Fall & I & $x$ & & Yes \\
\hline 13 & 44 & $M$ & Có & I969/Fall & 3 & $\times$ & & Yes* \\
\hline I4 & $2 I$ & $M$ & C6 & I970/Lacrosse & 6 & $x$ & $x$ & Yes* \\
\hline 15 & $4 I$ & M & $\mathrm{C} 8$ & I971/Fall & 3 & $x$ & & Yes* \\
\hline 16 & 25 & $M$ & $\mathrm{C}_{5}$ & I97 I/Truck & 2 & $\times$ & & Yes* \\
\hline I 7 & 15 & M & $\mathrm{C}_{5}$ & I97I/Fighting & I & $x$ & & Yes \\
\hline I8 & 18 & $\mathrm{M}$ & C6 & I97 I/Automobile & 2 & $\times$ & & Yes* \\
\hline I9 & I6 & M & C6 & I971/Football & 4 & $x$ & & Yes* \\
\hline 20 & 20 & M & $\mathrm{T}_{4}$ & I97I/Automobile & 2 & & $x$ & No \\
\hline $2 \mathrm{I}$ & $3 I$ & $M$ & $\mathrm{C}_{7}^{\top}$ & I956/Football & I & $x$ & & No \\
\hline 22 & 37 & $\mathrm{M}$ & C6 & I969/Automobile & I & $x$ & & No \\
\hline 23 & 44 & $M$ & $\mathrm{C}_{5}$ & I972/Automobile & I & $\times$ & & No \\
\hline 24 & 33 & $\mathbf{M}$ & $T_{\text {I }}$ & I972/Fall & I & $\times$ & & Yes \\
\hline 25 & 33 & M & T6 & I972/Automobile & 2 & $\times$ & & No \\
\hline 26 & $2 I$ & $\mathrm{M}$ & $\mathrm{C}_{4}$ & I968/Diving & I & $\times$ & & Yes \\
\hline 27 & 27 & $\mathrm{~F}$ & $\mathrm{C}_{7}$ & I964/Automobile & I & $x$ & & No \\
\hline 28 & 40 & M & T6 & I973/Automobile & I & & $x$ & Yes \\
\hline 29 & 22 & $\mathrm{M}$ & T5 & I972/Fall & 4 & $\times$ & & No \\
\hline 30 & I4 & $\mathrm{F}$ & $\mathrm{C}_{5}$ & I973/Diving & I & $x$ & & Yes \\
\hline $3 I$ & I8 & M & TI & I972/Motorcycle & 4 & $\times$ & & Yes* \\
\hline 32 & I8 & $M$ & $\mathrm{C}_{7}$ & I973/Motorcycle & I & $\times$ & & Yes \\
\hline 33 & I8 & $\mathbf{M}$ & C6 & I973/Diving & I & $\times$ & & Yes \\
\hline 34 & I 8 & $M$ & $\mathrm{C}_{5}$ & I973/Diving & I & $x$ & & Yes \\
\hline 35 & I8 & $M$ & T6 & I973/Motorcycle & 2 & $\times$ & & Yes* \\
\hline 36 & 26 & $M$ & $\mathrm{C}_{5}$ & I973/Diving & I & $\times$ & & Yes \\
\hline 37 & 23 & $\mathrm{~F}$ & $\mathrm{~T}_{4}$ & I973/Automobile & $\mathrm{I}$ & $\times$ & & No \\
\hline 38 & 20 & M & $\mathrm{C}_{7}$ & I972/Trampoline & 2 & $\times$ & & Yes $\star$ \\
\hline 39 & 39 & $M$ & $\mathrm{C}_{5}$ & I972/Automobile & I & $x$ & & Yes \\
\hline 40 & I8 & $\mathrm{M}$ & $\mathrm{C}_{5}$ & I973/Automobile & 2 & $x$ & & Yes* \\
\hline 4I & 34 & M & $\mathrm{C}_{5}$ & I960/Diving & I & $x$ & & Yes \\
\hline 42 & 43 & $M$ & TI & r964/Fall & I & $x$ & & Yes \\
\hline 43 & 23 & $M$ & $T_{3}$ & I974/Diving & 2 & $\times$ & & Yes $\star$ \\
\hline 44 & 20 & M & T6 & I974/Motorcycle & I & $\times$ & & No \\
\hline 45 & 22 & $M$ & $\mathrm{C}_{5}$ & I974/Motorcycle & I & $\times$ & & Yes \\
\hline 46 & I6 & M & $\mathrm{C}_{4}$ & I974/Automobile & I & & $x$ & Yes \\
\hline 47 & 59 & $M$ & C6 & I974/Automobile & $I$ & $\times$ & & No \\
\hline 48 & I5 & $M$ & C6 & I974/Automobile & I & $x$ & & No \\
\hline 49 & 56 & $M$ & $\mathrm{C}_{5}$ & I974/Industrial & $\mathbf{I}$ & $\times$ & & No \\
\hline 50 & 20 & $\mathrm{M}$ & $T_{5}$ & I974/Automobile & I & $x$ & & No \\
\hline $5 \mathrm{I}$ & 28 & $M$ & T6 & I974/Automobile & $I$ & $x$ & & No \\
\hline 52 & 17 & M & $\mathrm{T}_{5}$ & I972/Gymnastics & I & $x$ & & No \\
\hline 53 & I7 & $M$ & C6 & I974/Fall & I & $\times$ & & Yes \\
\hline 54 & 20 & M & C6 & I968/Automobile & I & & $x$ & Yes \\
\hline 55 & 33 & M & $\mathrm{C}_{5}$ & I972/Diving & I & & $x$ & Yes \\
\hline 56 & 54 & $\mathrm{M}$ & $\mathrm{C}_{4}$ & I975/Industrial & 2 & $x$ & & Yes $\star$ \\
\hline 57 & 28 & $\mathrm{M}$ & $\mathrm{C6}$ & I964/Automobile & 4 & $x$ & & Yes* \\
\hline
\end{tabular}

$\star$ There was increased systolic BP during all cystoscopic procedures 
autonomic hyperreflexia was seen during cystoscopy in any of the 45 patients with sensorimotor levels below $\mathrm{T}_{7}$. The appearance of the autonomic hyperreflexia was not influenced by the presence or absence of sedative, local, or general anaesthetic drugs.

In the 40 hyperreflexic patients, the increase in systolic blood pressure ranged between 40-1 20 torr, and the decrease in heart rate ranged between 40-60 beats/ minute. The severe hypertension was controlled with slow intravenous administration of trimethaphan 0.I per cent, I0-50 mg. No therapy was necessary for the bradycardia.

\section{Discussion}

Autonomic hyperreflexia is a syndrome observed in patients with spinal cord lesion above most of the sympathetic nerve outflow from the spinal cord, above $\mathrm{T}_{7}$ segment (Barbaric, I976; Campbell \& Harrison, I970). Because the major splanchnic outflow comes from the $\mathrm{T}_{4}$ or $\mathrm{T} 6$ to $\mathrm{L}_{2}$ segment of the spinal cord, autonomic hyperreflexia results from lesions above this level. Autonomic hyperreflexia is characterised by exaggerated autonomic responses to stimuli from distension of pelvic viscera, bladder or rectum (Quimby et al., 1973). Less often, it results from manipulation of the renal pelvis and intestines and from skin stimulation below the lesion.

The onset of symptoms and signs varies greatly, depending not on the return of reflex function in the patient's spinal cord but on the level of the injury and the completeness of the spinal section. It is reported that 66-85 per cent of quadriplegics and high paraplegics show this altered physiologic response (Bors, I956).

The afferent pathway involved in autonomic hyperreflexia responds as follows: Sensation from the bladder travels through pelvic splanchnic (parasympathetic $S_{2-3-4}$ ), pudendal (somatic $S_{2-3-4}$ ), and hypogastric (sympathetic $T_{9}$ or higher) nerves. Mucosal sensation travels through pelvic and hypogastric nerves into spinothalamic tracts, then higher. The efferent pathway is the sympathetic outflow, the splanchnic outflow T5-I I being the most important limb (Bors, 1957; Lapides \& Lovegrove, 1965; Johnson et al., 1975; Sabiston, 1972).

The mechanism of occurrence of the autonomic hyperreflexia has not yet been explained definitively. The most satisfactory attempt at explanation of this mechanism is the statement that, with stimulation, reflex motor outflow through neurons in the lateral horns causes spasm of the pelvic viscera and arteriolar spasm (thereby hypertension), pilomotor spasm, and sweating. In the person with an intact neuraxis, the reflexes described are inhibited in part by the outflow from higher centres, however, in the quadriplegic or high paraplegic patient, the failure of these inhibitory impulses to reach the effectors results in autonomic hyperreflexia.

Sensory stimulation of a distended bladder produces a reflex vasconstriction below the level of spinal cord transection, with an abrupt increase in systolic blood pressure. Aortic arch and carotid sinus pressor receptors are excited, producing vagal stimulation and vasomotor centre inhibition, with resulting bradycardia. However, due to the sympathetic pathways interruption of the synapsial controls, compensatory vasodilation can occur only above the level of the spinal cord lesion.

In full-blown paroxysmal hypertension, which increases the risk of acute heart failure and cerebral or retinal haemorrhage (Nieder et al., 1970), the lesion must be above the splanchnic outflow, i.e., above $\mathrm{T}_{7}$ (Guttmann \& Whitteridge, 1947). Patients with lesions between T8-IO will show only mild blood pressure evelation, 
and those with lesions below T Io will have only insignificant changes or no changes at all (Guttmann \& Whitteridge 1947; Kendrick et al., 1953; Feustel, 1976).

In the present study, autonomic hyperreflexia occurred in 40 of 57 patients (70 per cent) with spinal cord lesions above $\mathrm{T}_{7}$ during cystoscopy. This rate of 70 per cent falls well within the 66-85 per cent rate quoted for previous studies (Bors \& Comarr, I97I). We have not observed manifestations of autonomic hyperreflexia in patients with spinal cord lesions below $\mathrm{T}_{7}$.

The autonomic hyperreflexia was controlled satisfactorily during cystoscopy with trimethaphan 0.1 per cent. We feel that trimethaphan, an autonomic gangliablocking agent, is a safe and very effective drug in controlling the severe hypertension of autonomic $1, y$ perreflexia during cystoscopic procedures.

Local anaesthesia of the bladder mucosa can prevent stimuli arising at the mucosa from reaching the spinal cord. However, this type of anaesthesia will not prevent the excitation of muscle stretch receptors in the bladder wall, which are responsible for triggering the abnormal reflex arc.

\section{SUMMARY}

Cystoscopic procedures were performed on 102 patients with histories of traumatic spinal cord lesion; 57 patients had sensorimotor levels above $\mathrm{T}_{7}$, and the remaining 45 patients had levels below $T_{7}$. In 40 of the 57 patients ( 70 per cent) with levels above $\mathrm{T}_{7}$, signs and symptoms of autonomic hyperreflexia were seen during bladder distention and cystoscopy; the remaining 17 of these patients (30 per cent) did not have this response. No autonomic hyperreflexia was seen during cystoscopy in any of the 45 patients with sensotimotor levels below $\mathrm{T}_{7}$.

In the autonomic hyperreflexia patients, the increase in systolic blood pressure ranged between 40-120 torr, and the decrease in heart rate ranged between 40-60 beats/minute. The severe paroxysm of hypertension was controlled with a slow intravenous infusion of trimethaphan 0.1 per cent, IO-50 mg. No therapy was necessary for the bradycardia. The appearance of the autonomic hyperreflexia was not influenced by the presence or absence of sedative drugs, local or general anaesthesia.

No apparent complications occurred during the intraoperative or postoperative period other than, in two patients, the appearance of a mild allergic reaction with skin manifestations following intravenous injection of trimethaphan.

\section{RÉSUMÉ}

On a fait les procédures cystoscopiques en 102 malades qui avaient eu les histories des blessures de la colonne vertébrale; 57 malades avaient eu les niveaux au-dessus $\mathrm{T}_{7}$; et le reste des avaient maladies eu les niveaux sous $\mathrm{T}_{7}$. Parmi les 40 malades des 57 qui avaient eu les niveaux au-dessus $\mathrm{T}_{7}$ (70 per cent), on a observé les indicés et symptômes de l'hyperreflexia autonomique au cours de la distention de la vessie et de la cystoscopie; les I 7 malades qui restaient (30 per cent) n'ont pas eu de même réaction. On n'a pas observé d'hypereflexia autonomique aux malades avec les niveaux sous $\mathrm{T}_{7}$.

Chez les malades avec l'hypertension autonomique l'augmentation de la tension artérielle systolique s'échelonnait entre 40 et I 20 Torr et la diminution de la pulse s'échelonnait entre 40 et 60 battements $/ \mathrm{min}$.

Le paroxysme sévère de l'hypertension était controlé par une lente infusion intraveineuse de trimetaphan $0^{\circ}$ I per cent, IO-50 mg. Aucune therapie n'était pas necessaire pour la bradycardie. La présence ou l'absence des sedatives ou de l'anesthesie régionale ou génerale n'influaient pas l'apparition de l'hypertension autonomique.

Il n'y avait pas de complications apparentes dans la periode intraou postoperatiore sauf l'apparition en duex malades d'une reaction allergique légère avec manifestation cutanée apres l'injection intraveineuse de trimethaphan.

$$
\text { I } 5 / 4-D
$$




\section{ZUSAMMENFASSUNG}

IO2 Patienten mit der Krankengeschichte der traumatischen Rückenmarkquerschnittläsion waren cystoscopiert; 57 Patienten hatten die Grenze der Sensibilitätsstörung und der motorischen Lähmung abwärts D7, die verbleibenden 45 Patienten hatten die Grenze unterhalb D7. Wir haben die Symptome der vegetativen Hyperreflexie geshen bei 40 (70 per cent) zwischen 57 Patienten mit der sensibilität-motorischen Grenze abwärts D7 während der Ausdehnung der Harnblase und der Cystoscopie; die verbleibenden I7 (30 per cent) demonstrierten nicht solche Reaktion. Man hat keine vegetative Hyperreflexie während der Cystoscopie bei 45 Patienten mit der sensibilität-motorischen Grenze unterhalb D7 gesehen. Bei den Patienten mit der vegetativen Hyperreflexie variierte die Erhöhung des systolischen Blutdrucks zwishen 40-I20 Torr während die Senkung der Pulsfrequenz von 40-60 Pulsationen/min demonstriert war. Schwerere Paroxysmen der Hypertonie kontrollierten wir mit langsamer Infusion des Trimethaphan O I per cent, IO-50 mg. Was die Bradykardie betrifft, wares keine spezielle Therapie notwendig. Dic Anwesenheit bzw. Abwesenheit der Beruhigungsmittel und der lokalen oder allgemeinen Anesthesie beinflusste die Erscheinung der vegetativen Hyperreflexie nicht.

Im Verlaufe der intraoperativen und postoperativen Periode waren keine wesentlichen Komplikationen bemerkbar. Nur bei 2 Patienten beobacheteten wir einc milde allergische Reaktion mit Hautmanifestationen, die nach intravenösen Injection des Trimethapan eintraten.

\section{REFERENCES}

BARBARIC, Z. L. (1976). Autonomic dysreflexia in patients with spinal cord lesions: complications of voiding cystourethrography and ileal loopography. Am. F. Roentgenol., I27, 293-295.

Bors, E. (I956). The challenge of quadriplegia. Bull. Los Angeles Neurol. Soc. 21, I05-I 23.

Bors, E. (1957). Neurogenic bladder. Urol. Survey, 7, 177-250

Bors, E. \& Comarr, A. E. (I97I). Neurological Urology. University Park Press, Baltimore, pp. 86-90.

Campbell, M. F. \& Harrison, J. H. (1970). Urology. Saunders, Philadelphia, 3rd edition, pp. $1360-1363$.

Desmond, J. (1970). Paraplegia: problems confronting the anaesthesiologist. Can. Anaesth. Soc. F., I 7, 435-45I.

Feustel, D. (1976). Autonomic hyperreflexia. Amer. F. Nur., 76, 228-230.

Guttmann, L. (1976). Spinal Cord Injuries. Blackwell Scientfic Publication, Oxford, 2nd edition, pp. 352-367.

GutTMANN, L. \& WhitTeridge, D., (1947). Effects of bladder distention on autonomic mechanisms after spinal cord injuries. Brain, 70, 36I-404.

HeAD, H. \& RidDOCH, G. (I9I7). The automatic bladder, excessive sweating and some other reflex conditions, in gross injuries of the spinal cord. Brain, 40, I88-263.

Johnson, B., Thomason, R., Pallares, V. \& Sadove, M. S. (1975). Autonomic hyperreflexia: A review. Mil. Med. 140, 345-349.

Kendrick, W. W., SCOtT, J. W. Jousse, A. T.\& BotTerell, E. H. (I953). Reflex sweating and hypertension in traumatic transverse myelitis. Treatment Serv. Bull. (Ottawa), $8,437-448$

KURNICK, N. B. (1956). Autonomic hyperreflexia and its control in patients with spinal cord lesions. Ann. Int. Med., 44, 678-686.

Lapides, J. \& Lovegrove, R. H. (I965). Urinary vesicovascular reflex. F. Urolog., 94, 397-40I.

Nieder, R. M., O’Higgins, J. W. \& Aldrete, J. A. (1970). Autonomic hyperreflexia in urologic surgery. F.A.M.A, 213, 867-869..

Quimby, C. W., Williams, R. N. \& GReifenstein, F. E. (1973). Anesthetic problems of the acute quadriplegic patient. Anesth. Analg. (Cleveland), 52, 333-340.

Sabiston, D. C. (1972). Textbook of Surgery. Saunders, Philadelphia, Ioth edition, pp. I 528-I 536. 